\title{
Para-Sosyal İlişkinin Ürün Yerleștirme Çerçevesinde Marka Beğenilirliğine Yansıması
}

- Mevlüt Sedat Dönmez Dr. Öğr. Üyesi. Süleyman Demirel Üniversitesi sedat.donmez@gmail.com ORCID ID: 000-0002-84377416

\section{ÖZET}

Tüketicilerin, markanın pazarlama ve iletişim faaliyetlerine yönelik verdikleri yanitları etkileyen psikolojik faktör marka beğenilirliği olarak değerlendirilmektedir. Bu noktada markalar, ürün yerleştirme uygulamaları ile tüketicilerde bir beğenilirlik sağlamak adına dizi karakterleriyle bireyler arasinda kurulan para-sosyal ilişkiden faydalanmaktadır. Para-sosyal ilişki çerçevesinde bireyler dizi karakterini sanki gerçek bir arkadaşıymış gibi algılamaktadır. Bu iliş̧ki derinleştikçe tüketiciler karakterleri bir rol model olarak görmekte ve markaya yönelik değerlendirmelerini yönlendirmektedir. $\mathrm{Bu}$ bağlamda araştırmada tüketicilerin dizi karakterleriyle geliştirdikleri para-sosyal ilişki ile marka beğenilirliği oluşumu arasındaki uyumun sorgulanması amaçlanmıştır. Bu amaç doğrultusunda araştırmada yüz yüze anket tekniği ile Isparta ilinde amaçlı örneklem ile 422 katılımcıdan veri toplanmıștır. Araștırma kapsamında değişkenler arası uyumu belirlemek adına yapısal eşitlik modellemesinden faydalanılmuştır. Gerçekleştirilen analiz sonucunda araştırma çerçevesinde belirlenen model çıktılarının kabul edilebilir uyum ile mükemmel uyum arasında olduğu sonucuna erişilmiştir. Bu kapsamda elde edilen bulgulardan hareketle ürün yerleştirme kapsamında marka beğenilirliği açılamada para-sosyal etkileşiminin yüksek etkiye sahip olduğu sonucuna erişilmişstir. Diğer bir ifadeyle ulaşllan örneklem çerçevesinde para-sosyal iliş̧kinin marka beğenilirliği oluşumunu güçlü düzeyde açıkladığı görülmektedir.

Anahtar Sözcükler: Marka Beğenilirliği, Para-Sosyal İlișki, Ürün Yerleștirme, Marka Yerleștirme, Marka. 


\section{The Reflection of Para-Social Relationship to Brand Likeability within the Framework of Product Placement}

- Mevlüt Sedat Dönmez Assist. Prof. Dr., Süleyman Demirel University sedat.donmez@gmail.com ORCID ID: 000-0002-84377416

\begin{abstract}
The psychological factor that affects the consumers' responses to the marketing and communication activities of the brand is considered as brand likeability. At this point, brands make use of the para-social relationship established between the characters of the series and the individuals in order to gain a likeability for consumers through product placement practices. Within the framework of para-social relationship, individuals perceive the character of the series as if they are a true friend. As this relationship deepens, consumers see characters as role models and direct their evaluations towards the brand. In this context, it is aimed to question the harmony between the para-social relationship that consumers develop with series characters and the formation of brand likeability. In line with this purpose, data were collected from 422 participants with a purposeful sampling in the city of Isparta using face to face questionnaire technique. Within the scope of the research, structural equation modeling was used to determine the fit between variables. As a result of the analysis, it was concluded that the model outputs determined within the framework of the research were between acceptable fit and perfect fit. Based on the findings obtained in this context, it has been concluded that the para-social interaction has a high effect in explaining brand likeability within the scope of product placement. In the words, within the framework of the sample reached, it is seen that the para-social relationship strongly explains the formation of the brand likeability.
\end{abstract}

Keywords: Brand Likeability, Para-Social Relation, Product Placement, Brand Placement, Brand. 


\section{GİRIŞ}

Rakip markalardan ayrışarak tüketici zihninde değeri bir konum elde etmek isteyen işletmeler, bireylerde bir marka beğenilirliği oluşturma çabası içerisine girmektedir. Bilişsel ve duygusal bileşenleri barındıran beğenilirlik, marka açısından bakıldığında, tüketicilerin markanın pazarlama ve iletişim faaliyetlerine yönelik vermiş oldukları yanıtları etkileyen psikolojik faktör olarak yorumlanmaktadır. Markanın tüketiciler açısından çekicilik algısı marka beğenilirliği olarak tanımlanmaktadır. Sadece satın alma sonrasında değil, öncesinde ve satın alma sırasında da oluşabilen marka beğenilirliği, tüketicilerin marka sadakati, tutumu ve satın alma niyetine yansıyan bir faktör olarak görülmektedir. $\mathrm{Bu}$ bağlamda markaların, tüketicilerde bir beğeni oluşturabilmek adına başvurdukları iletişim tekniklerinden biri de ürün yerleştirmedir. $\mathrm{Bu}$ çerçevede işletmeler, markalarını, medya içeriklerinin içerisine konumlandırarak tüketicilere tanıtmaktadır. Bu kapsamda en sık kullanılan tekniklerden biri ise markayı dizi karakterlerine kullandırmaktır. Özellikle, tüketicilerin dizi karakterlerini sanki gerçek bir arkadaşlarıymış gibi değerlendirdikleri para-sosyal ilişki, ürün yerleştirme etkililiğine katkı sağlayabilmektedir. Tüketiciler, belirli bir dizi karakteriyle olan para-sosyal ilişkisini derinleştirdiğinde, o karakter, bireyler için bir rol model olarak görülmektedir. Böylece tüketiciler, marka tercihlerini ve değerlendirmelerini dizi karakteriyle geliştirdiği parasosyal ilişki doğrultusunda yönlendirmektedir. Dolayısıyla dizi karakterinin kullandığı markalar, tüketiciler için de tercih edilebilir görünmekte ve karaktere yönelik beğeni değerlendirmelerinin markaya yansıyacağı ön görülmektedir.

$\mathrm{Bu}$ varsayımdan hareketle araştırma kapsamında, ürün yerleştirme çerçevesinde parasosyal ilişkinin marka beğenilirliğine yansımasını irdelemek amaçlanmaktadır. Araştırma çerçevesinde 18 yaş üzeri katılımcılardan amaçlı örneklem ile yüz yüze anket tekniği ile veri toplanması hedeflenmektedir. Gerçekleştirilen literatür taraması kapsamında ulusal ve uluslararası literatürde değişkenler arası ilişkiyi irdeleyen bir araştırmaya rastlanmamıştır. $\mathrm{Bu}$ bağlamda çalışmanın ilk kez irdelenecek olmasıyla literatürdeki boşluğa katkı sunulacağı düşünülmektedir. Bunun yanı sıra değişkenler arası ilişkinin ilk kez irdelenecek olması, sonuçların bundan sonraki süreçte konuyla ilgili gerçekleştirilen araştırmalara destekleyici bir bilgi sunması ve yapılacak çalışmalara 1şık tutması beklenmektedir. Ayrıca gerçekleştirilen bu 
çalışma, reklam ve marka uygulayıcılarına para-sosyal ilişkinin marka beğenilirliğine yansımasını aktarmak açısından önem taşımaktadır.

\section{PARA-SOSYAL İLIŞKİ KAVRAMI}

Para-sosyal ilişki, medya karakteriyle izleyiciler arasında yaşanan bir ilişki yanılsaması olarak tanımlanmaktadır. Bu durumda ünlü isimler, sanki bireyin çevresindeki bir arkadaşıymış gibi algılanmaktadır. Özellikle etkileyici bir hikâye örgüsü içerisinde yer alan dizi karakterleri bu ilişkiye olanak sağlamaktadır (Horton \& Wohl, 1956, s. 215). Para-sosyal ilişkide, birey ile karakter arasında zaman içerisinde paylaşılan deneyim ve etkileşimlerden bir samimiyet duygusu gelişmektedir. Böylece izleyicilerde karakter ile ilgili bir kanaat oluşmakta ve bireyler medyada yer alan kişileri bildiklerini ve anladıklarını düşünmektedirler (Derrick, Gabriel, \& Tippin, 2008, s. 261). Para-sosyal ilişki çerçevesinde, izleyiciler ile karakter arasında, tek taraflı ve gerçek olmayan, medya karakteri tarafından yönetilen bir ilişki kurulmaktadır (Baek, Bae, \& Jang, 2013, s. 2). Bununla birlikte bu süreçte ilişkinin çift taraflı olduğu izlenimi uyandırılmaktadır. İlişsinin en temel özelliklerinden birisi karakterin jest, mimik ve konuşma tarzını sanki yüz yüze konuşuyormuş gibi kurgulamasıdır (Horton \& Wohl, 1956, s. 217). Yakın çekimler ve izleyiciyi etkileyecek görsel teknikler de ilişkinin güçlenmesine katkı sunmaktadır. Böylece seyirci ile oyuncu arasındaki çizgi mümkün olduğunca ortadan kaldırılmaya çalışılmaktadır ve izleyiciler karakteri sanki çok yakından tanıyormuş hissine kapılmaktadır (Rubin, Perse, \& Powell, 1985, s. 156).

Para-sosyal ilişkinin kişilerarasında gerçekleşen ilişkilere benzer bir yapı içerdiği söylenebilir. Bireylerin, gerçek yaşamda arkadaşlarına, eşlerine ve yakın çevresine nasıl tepki veriyorsa, para-sosyal ilişki içerisine girdiği medya karakterine de benzer bir tepki verdiği varsayılmaktadır (Branch, Wilson, \& Agnew, 2013, s. 97). Bu çerçevede Perse ve Rubin (1989) da para-sosyal etkileşimlerin, üç şekilde kişilerarası arkadaşlığa benzediğini belirtmektedir. İlk olarak, para-sosyal ilişkiler (arkadaşlıklar gibi) gönüllülük esasına dayanır ve genellikle kişisel bir odak içermektedir. İkincisi, her iki tür ilişki de arkadaşl1k sağlar ve üçüncüsü, sosyal çekim her iki tür ilişkinin de önemli bir ön koşulu olarak değerlendirilmektedir. Bununla birlikte parasosyal ilişkide yüz yüze etkileşim ya çok azdır veya hiç yoktur. İzleyicinin bir medya karakteriyle birebir tanışma olasılığı düşüktür (Derrick, Gabriel, \& Tippin, 2008, s. 262). 
Para-sosyal ilişkiler, bilişsel, duygusal ve davranışsal boyutları içerebilmektedir (Tsiotsou, 2015, s. 404). İzleyicilerin, medya karakteri ile aralarında bir arkadaşlık duygusu inşa etmesi ve bu kişilikleri kendi arkadaşları gibi algılaması ilişkinin duygusal boyutunu açıklamaktadır. Bireylerin mesajlar üzerine zihnini yorması ve düşünce süzgecinden geçirmesi ise ilişkinin bilişsel boyutunu açıklarken, sunulan içerik hakkında konuşulması, izleyicilerin özdeşleştiği karakteri yakından takip etmesi, onu desteklemesi, mesaj aracılığıyla ulaşmaya çalışması ise davranışsal boyutu ifade etmektedir (Alan \& Perse, 1987, s. 247-248). Para-sosyal ilişki, izleyicinin içeriğe olan sevgi ve sadakatini güçlendirmekte, gerçeklik algısı ve yakınlık hissi sağlamaktadır (Cohen, 1997, s. 518). Bu duygular, bireyin medya içeriğini izlediği anın ötesine geçerek, bir izlemeden diğerine devam etmektedir (Eyal \& Cohen, 2006, s. 504).

\section{ÜRÜN YERLEŞTIRME KAVRAMI VE ÖNEMI}

Artan reklam karmaşası, tanıtım maliyetleri ve tüketicilerin neyi nasıl izleyecekleri yönünde kontrolü ele almasını sağlayan teknolojik gelişmeler, ürün yerleştirme uygulamalarının markaların iletişim stratejisi içerisinde önem kazanmasına katkı sunmaktadır (Rusell \& Belch, 2005, s. 73). Ürün yerleştirme, medya programlarında, markalı ürünlerin veya marka tanımlayıcılarının, sesli veya görsel tekniklerle, ücretli biçimde içeriğe dahil edilmesi olarak tanımlanmaktadır (Balasubramanian, Karrh, \& Patwardhan, 2006, s. 115). Diğer bir tanıma göre marka-ürün yerleştirme, reklamverenin, program yapımcısına bir ücret karşılığında, markasını anlatı içeriğine dahil ettiği tanıtım aracı olarak yorumlanmaktadır (Karrh, 1998, s. 31). Ürün yerleştirme, bir markayı tanıtmanın doğal, agresif olmayan ve direk olarak ikna edici görünmeyen bir yöntemidir (Balasubramanian, Karrh, \& Patwardhan, 2006, S. 115).

Geleneksel reklamcılığa alternatif olarak görülen ürün yerleştirme, medya içeriğine ilişkilendirildiği için tüketicilerin reklamdan kaçma sorununu da ortadan kaldırmaktadır (Van Reijmersdal, Neijens, \& Smit, 2007, s. 403). Tüketiciler, markalara ve ürünlere medya içeriklerinin doğal süreci sırasında maruz kalmaktadır. Özetle ürün yerleştirme, markaları doğal ortamlarında kullanırken veya tüketirken göstermektedir (Williams, Petrosky, Hernandez, \& Page, 2011, s. 2). Bu çerçevede markalar, filmler, diziler, televizyon yayınları, romanlar, bilgisayar oyunları, müzik videoları, bloglar, internet dizileri, tiyatro, müzikal (Balasubramanian, Karrh, \& Patwardhan, 2006, s. 115), dijital ve kablolu yayın televizyon programları, DVD’ler, dergiler, kitaplar, çizgi romanlar, radyo, internet ve cep telefonlarında 
kullanılan bir iletişim tekniği olarak karşımıza çıkmaktadır (Williams, Petrosky, Hernandez, \& Page, 2011, s. 1). Bu noktada ürün yerleştirmenin reklam ile eğlence arasındaki çizgiyi bulanıklaştırdığı için hibrit bir reklam türü olarak değerlendirildiği söylenebilir (Rusell \& Belch, 2005, s. 74).

Ürün yerleştirme, geleneksel reklam çabalarından daha geniş bir kitleye erişim sağlamasının yanı sıra içeriği takip eden bir tüketici topluluğuna ulaşmaktadır (Nelson, 2002). Ayrıca izleyici başına düşen maliyet açısından tercih edilebilir bir iletişim stratejisidir (D'Astous \& Chartier, 2000, s. 31). Böylece ürün yerleştirme aracılı̆̆g ile işletmeler, markalarına olumlu çağrışımlar oluşturabilmek adına, doğal ve güvenilir bir iletişim ortamı elde edebilmektedir (Van Reijmersdal, Neijens, \& Smit, 2007, s. 403).

Markanın pazarlama iletişimi faaliyetlerini destekler bir nitelik gösteren ürün yerleştirme (Rusell \& Belch, 2005, s. 82), markaların reklam karmaşası içerisinde kaybolma, izleyicinin yoğun mesaj aldığg durumda ilgisizliğine maruz kalma veya bir takım teknolojik unsurlardan dolayı reklam etkililiklerinin azalması gibi faktörlerden etkilenmemesi için uygun bir yöntem olarak görülmektedir. Bu çerçevede ürün yerleştirme ile markalar, tüketicilerle olumlu ilişkiler geliştirebilmekte ve hedefledikleri marka imajına katkı sağlayabilmektedirler (Smit, Van Reijmersdal, \& Neijens, 2009, s. 762). Ürün yerleştirme ayrıca markanın görünürlüğünü arttırmak, tüketicilerin dikkatini ve ilgisini çekmek, marka bilinirliğini arttırmak, marka hatırlanırlığı ve tanınırlığı sağlamak, tüketicilerin markaya yönelik tutumlarını ve değerlendirmelerini değiştirmek veya pekiştirmek (Williams, Petrosky, Hernandez, \& Page, 2011, s. 5; Matthes, Schemer, \& Wirth, 2007, s. 477; D'Astous \& Chartier, 2000, s. 32; Babin \& Carder, 1996; Brennan \& Babin, 2004; Karrh, McKee, \& Pardun, 2003) markayı denettirmek ve satın alma niyeti oluşturmak (Nelson, 2002; Rusell \& Belch, 2005, s. 86) gibi amaçlar taşıyabilmektedir.

Günümüzde ürün yerleştirmenin kullanım alanları ve teknikleri dijital iletişim ortamlarının gelişmesiyle daha da yükselmektedir (Williams, Petrosky, Hernandez, \& Page, 2011, s. 3). Özellikle dizi kurguları, hikâye ve formatları gereği, ürün yerleştirme uygulamalarına imkân sunan içerikler olarak görülmektedir (Balasubramanian, Karrh, \& Patwardhan, 2006, s. 115). Bu doğrultuda işletmeler, bir hikâye örgüsünün içerisine markayı dahil ederek o anki olayın bir unsuruymuş gibi sunmaktadırlar. Bu çerçevede oyuncuların çekicilikleri, içeriğin sunuluş biçimi de bu gerçeklik çabasını desteklemektedir (Karrh, 1998, s. 
31). Ürün yerleştirme dizilerde genel olarak iki biçimde yoğun şekilde kullanılmaktadır. Bu bağlamda reklamveren, ürünün veya markanın herhangi bir sahnede görünmesi için bu tekniği kullanabilmektedir. Bir diğer durumda ise içerik, marka mesajının etrafında biçimlenerek marka olay örgüsünün ayrılmaz bir parçası konumuna gelebilmektedir (Van Reijmersdal, Neijens, \& Smit, 2009, s. 430).

Dizi ve film gibi içeriklerde ürün yerleştirme uygulamalarının önem kazanmasında birtakım faktörlerin etkili olduğu düşünülmektedir. Bunlardan biri, reklam uygulayıcılarının film veya dizi gibi popüler olan medya içeriklerinin kendine özgü kurgu ve özelliklerinden faydalanma isteğidir. Bu özelliklerden biri medya içeriklerinin uzun raf ömürlerinin olmasıdır. Bunun yanı sıra film, dizi, izleyicilere görüntü ve sesi etkileyici bir atmosferde sunma yeteneğine sahiptir ve birçok medya içeriği güçlü bir ikna gücünü elinde bulundurmaktadır. $\mathrm{Bu}$ bağlamda birçok film veya dizinin bireylerin sosyal yargılarını etkileyebilme gücüne sahip olduğu bilinmektedir. Bireylerin medya içeriğini tüketmelerinde en güçlü motivasyonlar olarak görülen eğlence, stresten kaçma unsurları da göz önüne alındığında, tüketicilerin medya karakteri ve içeriğe duygusal ve bilişsel tepkiler vereceği ve bu tepkilerin ise markaya aktarılabileceği düşünülmektedir. Bu tekniğin önem kazanmasında bir diğer unsur ise medya içeriğinde yer alan ünlü karakterlerin markaya yönelik onayı örtük biçimde gerçekleştirebilmesidir (Karrh, 1998, s. 33-34). Markanın içerikle ilişkilendirildiği durumda, ürün yerleştirmenin reklam olarak algılanmayacağı düşünülmektedir (Van Reijmersdal, 2009, s. 152). Karakterin bir markayı kullanması, tüketicilerin de bu markayı beğenmelerini ve markaya yönelik olumlu bir tutum oluşturmasını sağlamaktadır (Yang \& Roskos-Ewoldsen, 2007, s. 470-471). Dolayısıyla ürün yerleştirmenin başarısı, yayında geçirilen sürenin uzunluğu, markanın hikayeye ne zaman ve nasıl ilişkilendirildiği ve hedeflenen kitle gibi bir takım faktörlere dayanmaktadır. Özellikle markanın hikayeye ilişkilendirilme biçimi önem taşımaktadır. Genellikle düşük düzeyde bir hikaye bağlantısı istenilen sonuçların alınmasının önüne geçmektedir (Williams, Petrosky, Hernandez, \& Page, 2011, s. 9-10).

\section{PARA-SOSYAL ILLIŞKININ ÜRÜN YERLEŞTIRME BAĞLAMINDA KULLANIMI}

Pazarlama ve reklamcılık bağlamında para-sosyal ilişki 'tüketicilerin, medya karakterleriyle sanki varmış ve karşılıklı ilişki içerisindeymiş gibi etkileşim haline girdiği 
yanıltıcı bir deneyim' olarak tanımlanmaktadır (Labrecque, 2014, s. 135). İzleyiciler, belirli bir medya karakteriyle para-sosyal ilişkisini derinleştirdikçe, o kişiyi, ürün veya marka tercihlerinde de bir rol model olarak görmektedirler. Böylece karakterin tercih ettiği markalar, izleyicilerin de tercihleri arasında girebilmektedir (Rusell \& Stern, 2006, s. 10). Bu durumda tüketiciye bir marka değil yaşam tarzı sunulmaktadır. Bu yaşam tarzı ise dizi karakteri aracılığıyla tüketiciye aktarılmaktadır. Sunulan yaşam tarzına ulaşabilmek ise karakterin kullandığı markalar aracılığıyla gerçekleşmektedir (Lueck, 2015, s. 103). İşletmeler ürün yerleştirme stratejilerinden faydalanarak, marka ile medya karakterini eşleştirmekte ve marka kimliğinin temsil edilmesini sağlamaktadır (Karrh, 1998, s. 31). Tüketiciler böylece izledikleri dizide yer alan karakteri beğendikleri ve onunla bir para-sosyal ilişki kurduğu durumda dizi karakterinin kullandığı markaları kullanarak arzuladıkları kimliklerini onaylayabilmektedirler (Scott \& Craig-Lees, 2010, s. 41). Ürün yerleştirmeler, genellikle dizi karakterinin markay1 kullanması ile gösterilmektedir. Kullanılan ürün yerleştirme uygulamaları ile marka değerine yönelik çağrışımlar izleyiciye aktarılmaktadır. Örneğin, karakterin Ray-Ban marka gözlüğü kullanması, karakterin havalı görünmesini sağlamaktadır (Schramm \& Knoll, 2015, s. 549). Böylece para-sosyal etkileşim aracılığı ile oluşan ünlü-izleyici bağı, bir ürün veya markaya yönelik duygusal bir bağa dönüşebilmektedir (Rusell \& Belch, 2005, s. 87). Dolayısıyla parasosyal ilişkinin tüketicilerin markaya yönelik tutum ve davranışını biçimlendirdiğini söylemek mümkündür (Liu, Liu, \& Zhang, 2019, s. 422).

Ürün yerleştirme ile para-sosyal etkileşim arasındaki ilişki Russell ve Stern (2006, s. 10) tarafından önerilen denge modeliyle açıklanmaktadır. Bu modele göre, tüketicilerin ürün yerleştirme sonucunda markaya yönelik tutumu ürün, tüketici ve karakter üçgeni bağlamında açıklanmaktadır. Bu çerçevede tüketicilerin tutumları, yerleştirme yapılan markaya yönelik tutumları, medya karakteriyle ilişkisi ve medya karakterinin ürünle olan bağlantısının tutarlılığın sonucunda biçimlenmektedir. Dolayısıyla, bir izleyicinin bir markaya yönelik tutumunun hem bir medya karakteriyle olan ilişkisinden hem de karakterin markayla olan ilişkisinden etkilendiği varsayılmaktadır. Ürün yerleştirme çerçevesinde düşünüldüğünde, izleyici, herhangi bir markaya yönelik tutumunu, medya karakterinin markaya yönelik tutumuyla aynı seviyeye getirmeye çalışacaktır. Dolayısıyla, tüketici eğer bir dizi karakteriyle para-sosyal bir ilişki içerisine girerse, ünlü kişinin dizi içerisinde kullandığı markaya da olumlu bir tutum sergileyecektir. Bunun yanı sira denge teorisi kapsamında tutumun olumlu ve 
olumsuz tarafı olduğu gibi güçlülük ve zayıflık durumu da göz önüne alınmaktadır. Ürün yerleştirme durumunda, tüketicilerin markaya yönelik tutumunun gücü, karakterin markayla uyumu ve tüketici ile karakterin para-sosyal ilişkisinden etkilenecektir. Güç ne kadar büyük olursa ilgili değerin etkisi de o kadar büyük olmaktadır. Eğer bir tüketici, dizi karakteriyle güçlü bir para-sosyal ilişki yaşarsa, bu durum bireylerin markaya yönelik tutumlarının değişmesine veya var olan tutumların pekişmesine etki edecektir (Williams, Petrosky, Hernandez, \& Page, 2011, s. 15). Tüketiciler böylece izledikleri dizide yer alan karakteri beğendikleri ve onunla bir para-sosyal ilişki kurduğu durumda, dizi karakterinin kullandığı markaları kullanarak arzuladıkları kimliklerini onaylayabilmektedirler (Scott \& Craig-Lees, 2010, s. 41). Örneğin, medya karakteri gibi kendilerini güçlü hissetmek isteyen bireyler, onun giydiği kıyafetleri alarak bunu sağlayacağını düşünebilir veya kadın karakterin kullandığı makyaj ürünüyle aynı çekiciliğe sahip olabileceğine motive olabilmektedir.

\section{MARKA BEĞENILIIRLIĞGi KAVRAMI VE BOYUTLARI}

Beğenilirlik, bir ikna tekniği ve kendini sunma durumu olarak tanımlanmaktadır (Reysen, 2005, s. 201). Beğenme durumu ise bireyin herhangi bir kişi veya nesneyi hoş olarak algılaması sonucu, o nesneye veya kişiye olan ilgisi olarak yorumlanmaktadır (Devrani, 2009, s. 411). Beğenilirlik, bilişsel ve duyuşsal bileşenleri olan, çok boyutlu bir yapı olarak karşımıza çıkmaktadır (Nguyen, Melewar, \& Chen, 2013a, s. 26). Marka beğenilirliği ise tüketicilerin bir marka ve markanın pazarlama faaliyetlerine yönelik gösterdikleri tepkileri etkileyen psikolojik bir faktör olarak tanımlanmaktadır (Nguyen, Choudhury, \& Melewar, 2015, s. 123). Bir diğer ifadeyle marka beğenilirliği, bir tüketicinin markaya yönelik sahip olduğu çekicilik algısının değerlendirmesi olarak açıklanırken, çok boyutlu bir yaklaşımla ise olumluluğun, etkileşimin, kişiselleştirmenin ve memnuiyetin değerlendirmesi olarak yorumlanmaktadır (Nguyen, Ekinci, Simkin, \& Melewar, 2015, s. 778-780). Güvenilirlik, uzmanlık ve çekiciliği kapsayan marka beğenilirliği, tüketicilerin sevgi çerçevesinde, markaya bağlanmalarını sağlayan bir strateji olarak ifade edilmektedir (Gökaliler \& Saatçioğlu, 2019, s. 177).

Marka beğenilirliği, sadece satın alım sonrasında değil, öncesi ve satın alım sırasında da gerçekleşebilecek bir sonuç olduğundan (Nguyen, Ekinci, Simkin, \& Melewar, 2015, s. 777) kaynağın güvenilirliği, çekicilik ve tüketicilerin dürüstlük, toplum normlarına uygunluk ve adil davranış çağrışımlarından, önceki deneyimlerinden, rakip markalar ve rakiplerin algılanan değeri gibi birçok faktörden etkilenen bir yapı olarak karşımıza çıkmaktadır (Nguyen, Melewar, 
\& Chen, 2013a, s. 31). Markaların mal veya hizmetlerini, iletişim bileşenlerini tüketicilere beğenilebilir bir deneyim oluşturabilmek adına tasarlamaları büyük önem taşımaktadır (Nguyen, Melewar, \& Chen, 2013b, s. 371). Marka beğenilirliği, tüketici ile marka arasında daha güçlü bir olumlu ilişki sağlarken, etkileşimi arttıracağı, kalite algısını ve marka memnuniyetini güçlendireceği, ağızdan ağıza iletişime katkı sağlayacağı, güçlü bir marka kimliği algısı, marka imajı, sadakati, aşkı, memnuniyeti, güveni ve satın alma niyeti oluşturacağı varsayılmaktadır (Nguyen, Ekinci, Simkin, \& Melewar, 2015, s. 783-794). Bunun yanı sıra marka beğenilirliği marka değerine etki eden önemli bir bileşen olarak ele alınmaktadır (Ye \& Van Raaij, 2004, s. 96).

Nguyen, Ekinci, Simkin ve Melevar (2015, s. 781-784) tasarladıkları marka beğenilirliği ölçeğinde, beğenilirliği olumluluk, etkileşim, kişiselleştirilmiş kalite ve hoşnutluk olarak dört boyut altında değerlendirmişlerdir. Bu noktada olumlu çağrışımlar, tüketicilerin markaya yönelik sahip olduğu iyimser tavrın oranına karşılık gelmektedir. Kısaca marka hakkında tüketici zihninde olumlu yönde fikirler oluşturmaktır (Yüksekbilgili, 2017, s. 171). Markaya yönelik olumlu değerlendirmeler atfedildiğinde, tüketicilerin markayı beğenilir bulması beklenmektedir. Olumluluk boyutu ise iyimserlik, olumlu çağrışımlar, avantajlı olma hissi ve markanın vaadini yerine getirebilmesine yönelik inançlardan etkilenmektedir. Bağımlılık, bağlılık, bilgi paylaşımı ve iletişim kalitesi alt bileşenlerini içeren marka beğenilirliği etkileşim boyutu ise tüketicilerin markayla etkileşimi ve iletişime geçme isteği olarak yorumlanmaktadır. Markayla etkileşime giren bireylerin, markaya yönelik beğenilirliklerinin oluşacağı veya güçleneceği varsayılmaktadır. Böylece tüketiciler markaları kendilerine yakın hissedecekler ve bir marka sadakati gösterme eğiliminde olacaklardır (Özden, 2019, s. 121). Samimiyet, erişebilirlik, çekicilik, bilgili olma ve dürüstlük bileşenlerini içeren kişiselleştirme boyutu ise tüketicilerin bireysel anlamda, kendileriyle ilgili olan şeylere daha olumlu tepki verme isteği içerisinde oldukları düşüncesinden beslenmektedir. Markalar, farklılaşabilmek ve tüketicilerin beğenilerini kazanabilmeleri için kişiselleştirme stratejisine büyük önem vermektedir. Marka beğenilirliğinin son boyutu olan marka memnuniyeti ise markanın tüketicileri memnun edecek ve markaya beğenilirliği oluşturacak bir deneyim sunmasıdır. Örneğin, tüketicilerin ilgi alanlarına dahil olmak, sosyal sorumluluk faaliyeti gerçekleştirmek gibi iletişim uygulamaları, bireylerin marka memnuniyetini ve beğenilirliğini güçlendirmektedir. Bu kapsamda marka beğenilirliğinin memnuniyet boyutunun onay, neşe, gönül rahatlığg ve tatmin olma yapılarından 
meydana geldiği söylenebilir. Tüketiciler gönül rahatlığı ile bir markayı tercih ettiğinde ve satın alma sonrasında vaadin tatminini deneyimleyeceğine inandığında, markaya yönelik beğenilirliklerinin artacağı varsayılmaktadır.

Para-sosyal ilişki açısından bakıldığında, ürün yerleştirme çerçevesinde dizi karakterine yönelik değerlendirmelerin, markaların beğenilirliklerine yansıyacağı varsayılmaktadır. Çünkü izleyiciler, sevdikleri karakterin kimlik özelliklerini ve eylemlerini takip etmektedirler. $\mathrm{Bu}$ bağlamda dizi içeriklerinde markalar, karakterin kendi kimliğini aktarmak ve izleyicide oluşan kimlik algısını pekiştirmek amaçlı bir rol üstlenmektedir. Bu durumda karakterin markalar aracılığı ile sunduğu kimlik, izleyiciler tarafından kabul edilebilir ve beğenilir olduğu durumda arzu edilir olmaktadır. Dolayısıyla bu beğenilirlik markaya yansımaktadır (Karrh, 1998, s. 43). Para-sosyal ilişki çerçevesinde gerçekleştirilen ürün yerleştirmenin, marka beğenilirliği ile ilişkili olan marka tutumu, sadakati, imajı, hatırlanırlığı üzerindeki etkisi, öncesinde test edilmiştir. Dolayısıyla bu değişkenin, marka beğenilirliği üzerinde de etki göstereceği varsayılmaktadır. Bu doğrultuda markalar, tüketicilerin zihninde bir beğenilirlik algısı oluşturabilmek adına, samimiyet, erişilebilirlik, çekicilik gibi değerlerine önem verirken, tüketici kitlesiyle benzerliğini güçlendirerek beğenilirliği etkileyebilecek çağrışım unsurlarını tasarlamaktadır. İşletmeler, reklam içeriklerinde ünlü kişileri kullanarak veya çeşitli televizyon ve internet yayınları içerisinde markalarını ünlü bireylere kullandırarak, tüketicilerde markaya karşı bir güven ve beğenilirlik oluşturulmaktadır (Nguyen, Choudhury, \& Melewar, 2015, s. 124). Bu sayede markalar, kaynağın güvenilirliğinden destek alarak işletmenin ürünleriyle dizi karakteri arasında olumlu bir ilişki kurmakta, böylece beğenilirlik sağlamaktadır. Bu noktada ünlü kişiler birer marka destekçisi görevi görmektedir (Nguyen, Melewar, \& Chen, 2013b, s. $370)$.

Marka beğenilirliği üzerine yerli ve yabancı literatür kapsamında sınırlı çalışmalar yer almaktadır. Bu çerçevede Rusell, Fortunato, Valencia ve Burns (2003) araştırmalarında televizyon reklamlarının marka beğenilirliğine etki ettiği bulgusuna erişirken, Sung, Kim, Kwon ve Moon (2010) ve Lim ve Kumar (2019) ise marka beğenilirliğinin sanal marka topluluğu bağlılığı oluşturmak noktasında önemli bir etken olduğu sonucuna ulaşmışlardır. Bunların yanı sıra Nguyen, Melewar ve Chen (2013a) ve Nguyen, Melewar ve Chen (2013b) marka beğenilirliğinin kavramlaştırılması üzerine gerçekleştirdikleri çalışmalarında, marka beğenilirliğinin bilişsel ve duygusal olarak iki bileşenli olduğunu belirlemişler ve beğenilirliğin 
marka aşkı, müşteri tatmini, marka itibarı, marka tercihi ve tutumlar üzerinde etkili olduğu sonucuna erişmişlerdir. Kwon, Kim, Sung ve Yoo (2014) ise araştırmalarında, marka beğenilirliğinin, tüketicilerin Twitter' da markaları takip etmeleri için etkili olduğu bulgusuna erişmiş ve bireylerin marka beğenilirliğinin yüksek olduğu durumda, daha güçlü bir marka kimliği algısına sahip olduklarına ulaşmışlardır. Nguyen, Choudhury ve Melewar (2015) çalışmalarında müşterilerin beğenilirlik değerlendirmelerini algılanan hizmet kalitesi, algılanan risk, fiyat hassasiyeti ve marka tanınırlığı çerçevesinde irdelemişler ve tanınırlığın marka beğenisini güçlendirdiği, algılanan risk ve fiyat hassasiyetini ise azalttığı sonucuna erişmişlerdir. Nguyen, Ekinci, Simkin ve Melevar (2015) ise bir marka beğenilirlik ölçeği geliştirmiştir. Yüksekbilgili (2017) ise geliştirilen bu ölçeği Türkçe’ye uyarlamıştır. Narteh (2018) ise marka değeri ile finansal performans arasındaki ilişkide marka beğenilirliğinin aracı etkisini tespit etmiş ve marka beğenilirliği ile finansal performans arasındaki ilişkiye erişmiştir. Gökaliler ve Saatçioğlu (2019) araştırmalarında, sanal dedikodu ile marka beğenilirliği arasında ilişki olduğunu ortaya koyarken, olumlu dedikodunun marka beğenilirliği üzerinde daha güçlü bir etkiye sahip olduğu bulgusuna ulaşmışlardır. Özden (2019) ise tüketicilerin özgüven düzeyleriyle marka beğenilirlikleri arasındaki ilişki olduğu bulgusuna erişmiştir. Bunun yanı sıra literatürde, para-sosyal ilişki çerçevesinde, ürün yerleştirme uygulamalarının marka ile ilişkisini irdeleyen araştırmalara rastlanmaktadır. D'Astous ve Chartier (2000), Balasubramanian, Karrh ve Patwardhan (2006), Matthes, Schemer ve Wirth (2007), Williams, Petrosky, Hernandez ve Page (2011), Scott ve Craig-Lees (2010), Nelson (2002) dizi karakteriyle gerçekleşen para-sosyal ilişkinin marka tanıma, hatırlama değişkenlerine etki ettiği sonucuna erişmişlerdir. Benzer sonuçlar elde eden Dens, De Pelsmacker, Wouters ve Purnawirawan (2012) ve Schramm ve Knoll (2015) oyuncunun markayı kullandığı durumlarda, izleyicilerin markaya yönelik hatırlama, tanıma ve tutumları üzerinde etkili sonuçlar olduğunu görürken, Yang ve Roskos-Ewoldsen (2007) ana karakterlerin kullandığı marka yerleştirmelerinin izleyici tarafından daha olumlu algılandığı sonucunu elde etmişlerdir. Janiszewski (1993), Russell (2002) ve Knooll, Schramm, Schallhorn ve Wynistorf (2015) ise dizi karakteri ile güçlü para-sosyal ilişki içerisinde olan bireylerin, ürün yerleştirme amaçlı kullanılan markaya yönelik olumlu bir tutum sergilediklerini tespit etmişlerdir. Russell ve Stern (2006), Schemer, Matthes, Wirth ve Textor (2008) yine marka tutumuna yönelik benzer sonuca ulaşmıştır. Xiang, Zheng, Lee ve Zhao (2016) para-sosyal ilişkilerin plansız satın alma davranışı üzerinde etkili olduğu bulgusunu elde ederken, Kim, Ko ve Kim (2015), Akıncı ve 
Çakır (2017) ilişkinin satın alma niyetine ve Labrecque (2014) marka sadakatine etkisine ulaşmışlardır. Chung ve Co (2017) ise para-sosyal ilişkiyle marka güvenilirliği ve satın alma niyetine ilişkisini tespit etmişlerdir. Lueck (2015) ise para-sosyal ilişkinin sosyal medya reklam etkililiğini arttırdığı bulgusuna erişirken Liu, Liu ve Zhang (2019) vloggerlar tarafından tanıtılan markaların algılanan kalitesi, marka etkisi ve marka tercihi üzerinde olumlu etkisi olduğu sonucunu elde etmişlerdir. Taşdelen (2020) ve Oyman ve Akıncı (2019) ise aynı etkinin satın alma niyeti özelinde gerçekleştiği bulgusuna ulaşmıştır. Hwang ve Zhang (2018) ise satın alma niyetine ek olarak olumlu ağızdan ağıza dedikodu oluşumunu ortaya koymuştur. Bunun yanı sıra Lee ve Watkins (2016) tüketiciler ile vloglar arsındaki para-sosyal ilişkinin lüks marka algısı ve lüks markalara yönelik satın alma niyeti oluşturulmasında etkili olduğunu tespit etmişlerdir. Paraosyal ilişkiyi çevrimiçi topluluklar açısından ele alan Ballantine ve Martin (2005) ise para-sosyal ilişki geliştiren bireylerin marka ve satın alma tercihlerinin de toplulukla aynı yönde değişeceği sonucunu ortaya koymuşlardır. Kim ve Kim (2018) tüketicilerin sosyal sorumluluk faaliyeti gerçekleştiren hava yolu firmalarına yönelik para-sosyal bir marka aşkı ilişkisi geliştirdiği sonucuna erişmişlerdir. Johnson ve Patnoe-Woodley (2016) ilişkinin markalara yönelik olumlu tutum, marka hatırlanırlığı ve satın alma niyeti üzerinde etkili olduğu bulgusuna ulaşmışlardır. Van Reijmersdal, Neijens ve Smit (2007)ise ilişkinin marka imajıyla olan olumlu ilişkisine erişmiştir.

\section{YÖNTEM}

Literatür kapsamında yukarıda bahsedilen araştırmalarda görüldüğü üzere para-sosyal ilişki çerçevesinde ürün yerleştirmenin marka tanıma, marka tutumu, plansız satın alma, satın alma niyeti, marka sadakati, marka aşkı değişkenleri ile arasındaki ilişkiyi sorgulayan araştırmalara rastlanmaktadır. Bunun yanı sıra literatür çerçevesinde marka beğenilirliği ile televizyon reklamları, sanal marka toplulukları, sosyal medya, algılanan kalite, marka tanınırlığı, sanal dedikodu oluşumu, tüketici özgüven düzeyleri, marka değeri ilişkisini irdeleyen çalışmalar görülürken, marka beğenilirliği kavramsallaştırılması ve ölçek geliştirilmesi üzerine sınırlı araştırma yapıldığı görülmektedir. Gerçekleştirilen araştırmalardan yola çıkarak, para-sosyal ilişkinin, tüketicilerin bilişsel ve duygusal değerlendirmelerini barındıran marka kavramlarıyla ilişskili bir unsur olduğu görülmektedir. Bu çerçevede taranan yerli ve yabancı literatür kapsamında, para-sosyal ilişki ile marka beğenilirliği arasındaki ilişkiyi irdeleyen bir araştırmaya rastlanmamaktadır. Bu açıdan para-sosyal ilişkinin ürün 
yerleştirme çerçevesinde marka beğenilirliğine yansımasının irdeleneceği bu araştırmanın ilk kez gerçekleştirilecek olması literatürdeki boşluğu doldurması açısından önem taşıyacağı düşünülmektedir. Bu bağlamda çalışmanın, uygulanan örneklem çerçevesinde bundan sonra marka beğenilirliği ile gerçekleştirilecek olan araştırmalara da destekleyici bir sonuç sağlaması beklenmektedir. Gerçekleştirilen çalışmanın literatüre katkı sağlamasının yanı sıra ürün yerleştirme uygulamalarını iletişim stratejilerinde kullanan iletişim uygulayıcılarına da bir veri sunacağı düşünülmektedir. Değişkenler arası ilişki açıklayan nedensel araştırma (Gegez, 2015, s. 48) niteliği gösteren bu çalışmada tüketicilerin dizi karakterleri ile geliştirdikleri para-sosyal ilişkinin ürün yerleştirme yapan markalara yönelik beğenilirliklerine yansımasının irdelenmesi amaçlanmaktadır.

\section{Veri Toplama Yöntemi}

Araştırma zaman ve maliyet kısıtından dolayı, Isparta ilinde yaşayan bireyler üzerinde, nicel araştırma yöntemi olan yüz yüze anket tekniğiyle gerçekleştirilmiştir. Araştırma, özelliklerine ortalama düzeyde uygun katılımcıların dahil edildiği ve evrenin genelini temsil edebilme yeteneğine sahip örneklem türü amaçlı örnekleme olarak adlandırılmaktadır (Özen \& Gül, 2007, s. 414). Bu bağlamda araştırma çerçevesinde televizyon veya internet üzerinde herhangi bir diziyi takip eden katılımcılara ulaşmak amaçlanmıştır. Problem çözümüne yönelik araştırmalarda örneklem sayısının 300 ile 500 arasında olması önerilmektedir (Malhotra \& Birks, 2000, s. 351). Bu kapsamda araştırmanın örneklemini 422 kişi oluşturmaktadır. Herhangi bir ürün kategorisi veya markayla sınırlandırılmayan çalışmanın tüm Türkiye’ye ve ürün, dizi kategorilerine genellenmesi mümkün değildir.

Çalışmada para-sosyal ilişkinin ürün yerleştirme bağlamında marka beğenilirliğine yansıması yapısal eşitlik modellemesi ile incelenmiştir. Araştırmanın anket formunun birinci bölümünde bireylerin dizi karakterleriyle kurdukları para-sosyal ilişkiyi ölçmek amaçlayan Rubin ve Perse (1987) tarafından düzenlenen ve Arda (2006) tarafından Türkçe'ye uyarlanan Para-sosyal Etkileşim Ölçeği kullanılmıştır. Ölçek 14 maddeden oluşmakta ve beşli likert (1= Hiç Katılmıyorum, 5= Tamamen Katılıyorum) formundadır. Anketin ikinci bölümünde ise 13 maddeden oluşan ve 7'li likert kullanılarak (1=Hiç Katılmıyorum, 7=Tamamen Katılıyorum) Nguyen, Ekinci, Simkin ve Melewar (2015) tarafından geliştirilen ve sonrasında Yüksekbilgili (2017) tarafından Türkiye'deki bireyler üzerinde test edilerek Türkçe’ye çevrilen “Marka 
Beğenilirliği Ölçeği” kullanılmıştır. Anketin son bölümünde ise katılımcılara cinsiyet, yaş, eğitim, gelir ve medeni durumlarına yönelik demografik sorular yöneltilmiştir.

Ölçeklerin faktör analizi gerçekleştirilerek ölçüm modelinin güvenilirliği ve geçerliliği sınanmıştır. Önerilen modelin test edilmesinde yapısal eşitlik modellemesinden faydalanılmıştır. Demografik değişkenleri değerlendirmek için frekans ve yüzdeler, yapısal eşitlik modelinin yapısal geçerliliğini belirlemek için ise $\chi 2$ / sd oranı, CFI, GFI, AGFI, NFI, RMSEA ve RMR indeksleri kullanılmıştır. Verilerin analizinde tanımlayıcı istatistikler için SPSS 25.0 paket programı, SEM için LISREL 8.7 programından faydalanılmıştır.

\section{Bulgular ve Değerlendirme}

Araştırma kapsamında elde edilen demografik veriler aşağıdaki tabloda sunulmaktadır.

Tablo 1: Demografik Özellikler

\begin{tabular}{|c|c|c|c|}
\hline & & $\mathrm{n}$ & $\%$ \\
\hline \multirow{2}{*}{ Cinsiyet } & Erkek & 206 & 48,8 \\
\hline & Kadın & 216 & 51,2 \\
\hline \multirow{6}{*}{ Yaş } & $18-24$ & 160 & 37,9 \\
\hline & $25-29$ & 110 & 26,1 \\
\hline & $30-34$ & 74 & 17,5 \\
\hline & $35-40$ & 36 & 8,5 \\
\hline & $41-45$ & 28 & 6,6 \\
\hline & 46 ve üzeri & 14 & 3,3 \\
\hline \multirow{5}{*}{ Ĕgitim durum } & İlköğretim & 38 & 9,0 \\
\hline & Lise & 96 & 22,7 \\
\hline & Önlisans & 76 & 18,0 \\
\hline & Lisans & 178 & 42,2 \\
\hline & Lisansüstü & 34 & 8,1 \\
\hline \multirow{4}{*}{ Hane toplam gelir } & $0-1000 T L$ & 32 & 7,6 \\
\hline & 1001-2999 TL & 134 & 31,8 \\
\hline & 3000-4999 TL & 168 & 39,8 \\
\hline & $5000-7999 T L$ & 72 & 17,1 \\
\hline
\end{tabular}




\begin{tabular}{llll}
$8000-11000$ TL & 10 & 2,4 \\
& $\mathbf{1 1 0 0 1}-\mathbf{1 5 0 0 0}$ TL & 4 & 0,9 \\
& $\mathbf{1 5 0 0 1 - 2 0 0 0 0 ~ T L}$ & 2 & 0,5 \\
\hline Medeni durum & Bekar & 302 & 71,6 \\
& Evli & 120 & 28,4 \\
\hline
\end{tabular}

Tablo 2'deki açıklayıcı faktör analizi sonuçlarına göre para-sosyal ilişki ölçeği Arda (2006) çalışmasıyla uyumlu olacak şekilde Empati kurma, Arkadaşlık ve İlgi olmak üzere 3 faktörden oluşmaktadır. Faktörlerin özdeğerleri, varyans açıklama oranları ve her bir maddenin faktör yükleri de Tablo 1'de verilmiştir. Bu üç faktörün toplam varyans açıklama oranı 67,672 olarak hesaplanmıştır.

Empati faktöründe "Onu doğal, ayakları yere basan biri kişi olarak görüyorum.” sorusu 0,778 ile en yüksek madde yüküne sahiptir. Arkadaşlık faktöründe "Dizinin gösterildiği zamanlarda en sevdiğim karakter bana adeta can yoldaşı oluyor." sorusu 0,822 ile en yüksek madde yüküne sahiptir. İlgi faktöründe ise "Bir gazete, dergi veya internet sitesinde onunla ilgili haber çıksa okurum.” sorusu 0,825 ile en yüksek madde yüküne sahiptir.

Tablo 2: Para-Sosyal Etkileşim Ölçeği Faktör Analizi Sonuçları

\begin{tabular}{ccc}
\hline Factor & Eigen & Explained \\
Lariance $(\%)$
\end{tabular}

\section{Empati Kurma}

Dizideki en sevdiğim karakter bir hata yaptığında veya bașından .533 olumsuz olaylar geçtiğinde onun adına üzülüyorum

Düşüncelerimi onun söyledikleri ile karşılaştırmaktan hoşlanıyorum

$$
7,406 \quad 52,900
$$

Onu doğal, ayakları yere basan biri kişi olarak görüyorum $\quad .778$

Onu çekici buluyorum

Diziyi izlerken bazen onun yaptıkları veya söyledikleri üzerine .646 sesli olarak yorum yapıyorum 
Dizideki en sevdiğim karakter sanki arkadaşlarımlaymışım gibi kendimi rahat hissetmemi sağliyor

Dizinin gösterildiği zamanlarda en sevdiğim karakter bana adeta can yoldaşı oluyor

Onu sanki eski bir akadaşımmış gibi iyi tanıyorum

En sevdiğim karakter bazı kararlar vermemde bana yardımcı olup yol gösteriyor
.735

.822

.779

\section{İlgi}

Dizideki en sevdiğim karakterin sesini duymak hoşuma gidiyor

Onu görmek için bir sonraki bölümü iple çekiyorum

Onunla şahsen tanışmak isterdim

Bir gazete, dergi veya internet sitesinde onunla ilgili haber çıksa okurum

Dizideki en sevdiğim karakter başka bir televizyon programına çıksa o programı seyrederim

Tablo 3'deki açıklayıcı faktör analizi sonuçlarına göre Marka Beğenilirlik Ölçeği orijinal ölçekte olduğu gibi Olumluluk, Etkileşim, Kişiselleştirilmiş Kalite ve Hoşnutluk olmak üzere 4 faktörden oluşmaktadır. Faktörlerin özdeğerleri, varyans açıklama oranları ve her bir maddenin faktör yükleri de Tablo 3 'te verilmiştir. Bu dört faktörün toplam varyans açıklama oranı 85,929 olarak hesaplanmıştır.

Olumluluk faktöründe "Dizideki en sevdiğim karakterin kullandığı markanın daha iyiye gideceğini düşünüyorum.” sorusu 0,725 ile en yüksek madde yüküne sahiptir. Etkileşim faktöründe "Dizideki en sevdiğim karakterin kullandığı markaya kendimi bağlı hissederim." sorusu 0,837 ile en yüksek madde yüküne sahiptir. Kişiselleştirilmiş Kalite faktöründe "Dizideki en sevdiğim karakterin kullandığı marka bana çok çekici gelir." sorusu 0,780 ile en yüksek madde yüküne sahiptir. Hoşnutluk faktöründe "Dizideki en sevdiğim karakterin kullandığ 1 markanın benim için her şeyi halledeceğini düşünürüm.” sorusu 0,874 ile en yüksek madde yüküne sahiptir.

Tablo 3: Marka Beğenilirliği Ölçeği Faktör Analizi Sonuçları 


\section{Olumluluk}

Dizideki en sevdiğim karakterin kullandığı markanın vaatlerini yerine .718 getireceğine inanıyorum

Dizideki en sevdiğim karakterin kullandığı marka bende olumlu bir algıyla özdeşleşir

Dizideki en sevdiğim karakterin kullandığı markanın bana iltimas ve .670 öncelik vereceğini hissediyorum.

Dizideki en sevdiğim karakterin kullandığı markanın daha iyiye

.725 gideceğini düşünüyorum

\section{Etkileşim}

Dizideki en sevdiğim karakterin kullandığı markaya bağımlı olduğum için markayı tercih etmeye devam ederim.

Dizideki en sevdiğim karakterin kullandığ 1 markaya kendimi bağl hissederim.

Dizideki en sevdiğim karakterin kullandığı markayla sürekli etkileşim içerisinde olurum.
.795

6,435

6,435

\section{Kișiselleștirilmiș Kalite}

Dizideki en sevdiğim karakterin kullandığı markayı arkadaşça olarak .646 tarif ederim.

Dizideki en sevdiğim karakterin kullandığı markanın ulaşılabilir olduğunu düşünürüm

$9,230 \quad 71,002$

Dizideki en sevdiğim karakterin kullandığı marka bana çok çekici gelir $\quad .780$

\section{Hoşnutluk}

Dizideki en sevdiğim karakterin kullandığı markayı genel olarak onaylarım.

Dizideki en sevdiğim karakterin kullandığı markadan alışveriş yaptığımda kendimi neşeli hissederim.

Dizideki en sevdiğim karakterin kullandığı markanın benim için her .832 şeyi halledeceğini düşünürüm.

$0,604 \quad 4,636$

.554

Aşağıda yer alan Tablo 4'de araştırmada kullanılan Para-sosyal etkileşim ve marka beğenilirliği ölçeklerine içsel tutarlılıklarına ilişkin Cronbach’s Alpha değerleri yer almaktadır. Elde edilen değerin kabul sınırları içerisinde yer aldığı görülmektedir.

Tablo 4: Ölçeklere İlişkin İçsel Tutarlılık Katsayıları 


\begin{tabular}{|c|c|c|}
\hline & İfade Sayısı & Cronbach's Alpha \\
\hline \multicolumn{3}{|c|}{ Para-Sosyal Etkileşim Ölçeği } \\
\hline Empati Kurma & 5 & 0,846 \\
\hline Arkadaşlık & 4 & 0,855 \\
\hline İlgi & 5 & 0,836 \\
\hline \multicolumn{3}{|c|}{ Marka Beğenilirliği Ölç̧eği } \\
\hline Olumluluk & 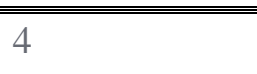 & 0,922 \\
\hline Etkileşim & 3 & 0,901 \\
\hline Kişiselleştirilmiş Kalite & 3 & 0,853 \\
\hline Hoşnutluk & 3 & 0,814 \\
\hline
\end{tabular}

Araştırmada Dens vd. (2012), Schramm ve Knoll (2015), Yang ve Roskos-Ewoldsen (2007), Janiszewski (1993), Russell (2002), Knooll vd. (2015), Russell ve Stern (2006), Schemer vd. (2008), Labrecque (2014), Johnson ve Patnoe-Woodley (2016), Van Reijmersdal vd. (2007) çalışmalarından yola çıkarak "Para-sosyal ilişki ürün yerleştirme çerçevesinde marka beğenilirliği üzerinde istatistiki olarak anlamlı ve yorumlanabilir bir şekilde etkilidir" hipotezi oluşturulmuştur. Hipotezin test edilmesine yönelik yapısal eşitlik modellemesi aşağıda gösterilmektedir. 


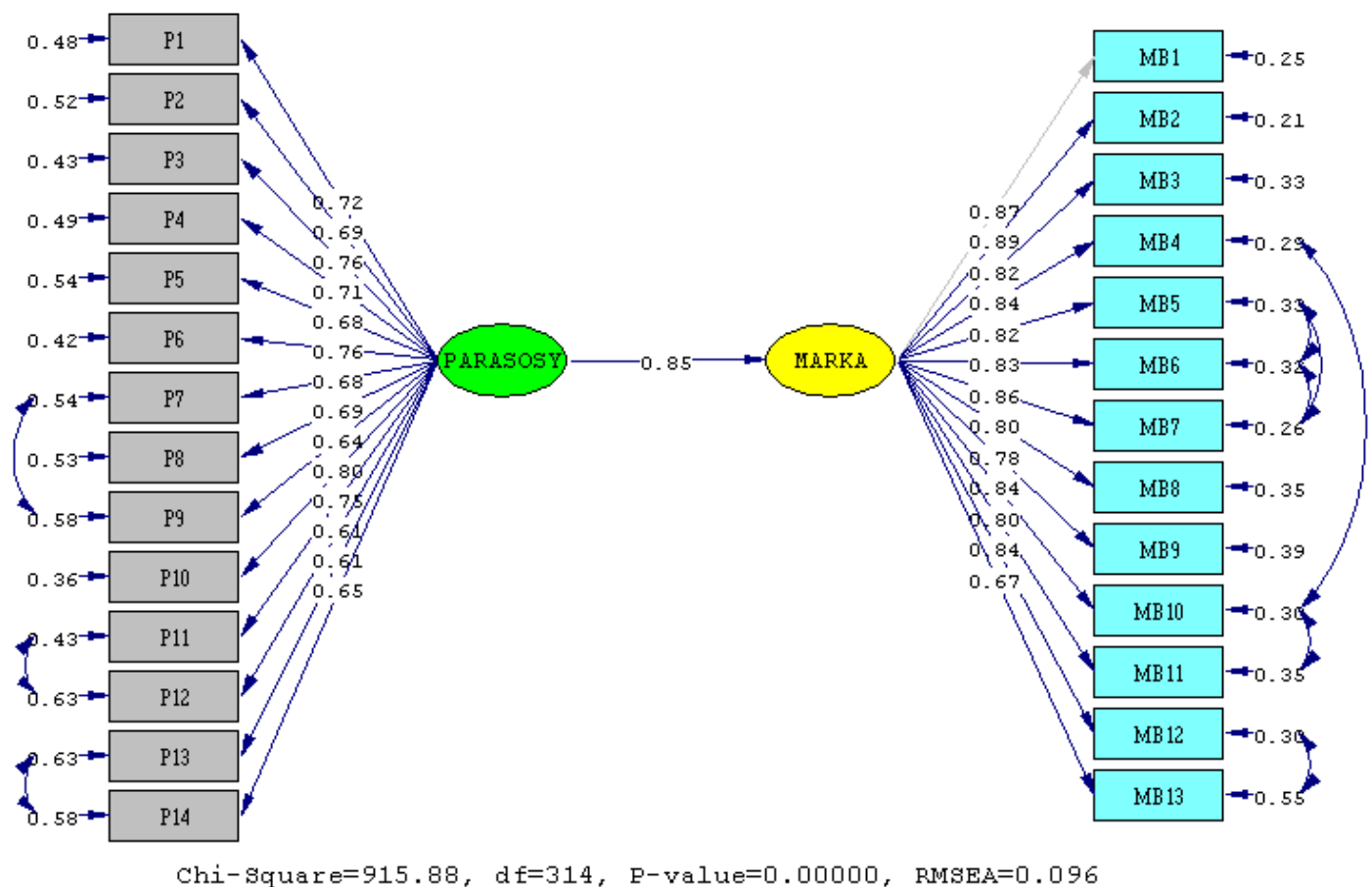

Şekil 1: Para-Sosyal Etkileşim ile Marka Beğenilirliğinin Yapısal Eşitlik

\section{Modellemesi ile İncelenmesi}

Uyum iyiliği istatistikleri ve Şekil 1'de verilen yapısal model için limitler Tablo 5'de verilmiştir.

Tablo 5: Uyum iyiliği istatistikleri

\begin{tabular}{llll}
\hline $\begin{array}{l}\text { Fitness } \\
\text { Criterion }\end{array}$ & Perfect Fitness & Acceptable Fitness & Model \\
\hline \hline RMSEA & $0 \leq \mathrm{RMSEA} \leq 0.05$ & $0.05<\mathrm{RMSEA} \leq 0.10$ & 0.096 \\
NFI & $0.95 \leq \mathrm{NFI} \leq 1$ & $0.90<\mathrm{NFI}<0.95$ & 0.96 \\
CFI & $0.97 \leq \mathrm{CFI} \leq 1$ & $0.95 \leq \mathrm{CFI}<0.97$ & 0.96 \\
SRMR & $0 \leq \mathrm{SRMR}<0.05$ & $0.05 \leq \mathrm{SRMR}<0.10$ & 0.054 \\
GFI & $0.95 \leq \mathrm{GFI} \leq 1$ & $0.90 \leq \mathrm{GFI}<0.95$ & 0.96 \\
AGFI & $0.90 \leq \mathrm{AGFI} \leq 1$ & $0.85 \leq \mathrm{AGFI}<0.90$ & 0.91 \\
\hline
\end{tabular}

Model çıktılarımızın kabul edilebilir uyum ile mükemmel uyum arasında olduğu bulunmuştur. $\mathrm{Bu}$ uyum iyiliği kriterlerinin yanı sıra, $\{\chi 2 / \mathrm{df}\}$ değeri 3 'ten düşükse, kabul 
edilebilir bir uyum olduğu anlamına gelir. Bu model için 915,88/314 = 2.91 olarak elde edilerek model istatistiksel olarak anlamlı bulunmuştur.

Para-Sosyal Etkileşim gizil değişkeni için faktör yükleri 0,61 ve 0,80 arasında değişmekte, Marka Beğenilirliği gizil değişkeni için faktör yükleri ise 0,67 ve 0,89 arasında değişmektedir. Standardize edilmiş regresyon (Beta) katsayılarına bakıldığında, Para-Sosyal Etkileşiminin, Marka Beğenilirliği üzerinde pozitif güçlü etkiye sahip olduğu $(B=0,85 ; p<0,01)$ görülmektedir. Ortaya çıkan bu bulgulardan hareketle, ürün yerleştirme kapsamında marka beğenilirliği açıklamada para-sosyal etkileşiminin yüksek etkiye sahip olduğu bulgusuna ulaşılmıştır. Bu noktada araştırma kapsamında varsayılan hipotez kabul edilmiştir. Diğer bir ifadeyle tüketicilerin izledikleri dizilerde para-sosyal etkileşim gerçekleştirdikleri dizi karakterlerinin kullandıkları markaya yönelik bireylerde bir marka beğenisi oluşabileceği ön görülmektedir. Bu bağlamda markalarına yönelik beğenilirlik sağlamak isteyen işletmelerin tüketicilerin para-sosyal ilişki kurdukları medya karakterleri aracılığı ile ürün yerleştirme çalışmaları yapmalarının istenilen sonuca katkı sağlayabileceği düşünülmektedir.

\section{SONUÇ}

İzleyicilerin medya karakterlerini bir arkadaşıymış gibi değerlendirdikleri ilişki yanılsaması para-sosyal ilişki olarak tanımlanmaktadır. Özellikle dizi karakterleri, bireylere etkileyici bir hikâye içerisinde sunuldukları için para-sosyal ilişki gelişimine olanak sağlayabilmektedir (Horton \& Wohl, 1956, s. 215). İzleyiciler bir dizi karakteri ile para-sosyal ilişki geliştirdiğinde, bu etkileşim, bireyin marka ve ürün tercihlerine ve markaları değerlendirmelerine de yansımaktadır. Çünkü izleyici, dizi karakterini kendine bu noktada bir rol model olarak görmektedir. Dizi karakterinin tercih ettiği bir marka, izleyici için de kabul edilebilir görünmektedir (Rusell \& Stern, 2006, s. 10).

Bu nedenle işletmeler, tüketicilerin takip ettikleri dizilerin hikaye örgülerinin içerisine markalarını dahil ederek, tüketicilerde markayla ilgili bir beğeni oluşturmak istemektedirler (Karrh, 1998, s. 31). Ürün yerleştirme olarak tanımlanan bu uygulama, markanın tanıtımı için doğal, agresif olmayan ve tüketicileri rahatsız etmeyen bir yöntem olarak değerlendirilmektedir (Balasubramanian, Karrh, \& Patwardhan, 2006, s. 115). Özellikle dizi kurguları, markaların doğal kullanım alanlarında gösterilebilen ve tüketicilerin markaya yönelik sahip olduğu çekicilik algısı (Nguyen, Ekinci, Simkin, \& Melewar, 2015, s. 778-780) olarak tanımlanan 
marka beğenisini sağlayabilen alanlar olarak görülmektedir. Bu kapsamda işletmeler, ürün yerleştirme ile markayla dizi karakterini eşleştirmekte ve marka kimliğini tüketicilere aktarmaktadır (Karrh, 1998, s. 31). Böylece tüketicilerin para-sosyal ilişki kurduğu karakterin kullandığı markanın bireyler tarafından beğenileceği ve arzulanacağı varsayılmaktadır. $\mathrm{Bu}$ varsayımdan yola çıkarak araştırma çerçevesinde, tüketicilerin dizi karakterleriyle kurdukları para-sosyal ilişkinin ürün yerleştirme bağlamında marka beğenilirliğine yansıyıp yansımayacağının irdelenmesi amaçlanmıştır.

Araştırma bağlamında belirlenen hipotezi test etmek adına yapısal eşitlik modellemesinden faydalanılmıştır. Gerçekleştirilen analiz doğrultusunda, model çıktısının kabul edilebilir bir uyum ile mükemmel uyum arasında olduğu tespit edilmiştir. Diğer bir ifadeyle araştırma çerçevesinde oluşturulan modelin istatiksel olarak anlamlı olduğu görülmekte ve hipotez onaylanmaktadır. Dolayısıyla araştırma kapsamında, para-sosyal etkileşiminin marka beğenilirliği üzerinde pozitif yönde güçlü bir etkiye sahip olduğu bulgusu elde edilmiştir. Ulaşılan bu bulgudan hareketle, marka beğenilirliğini açıklamada para-sosyal etkileşiminin, yüksek düzeyde bir etkiye sahip olduğu ifade edilebilmektedir. Başka bir ifadeyle araştırma çerçevesinde ulaşılan örneklem bağlamında, bireylerin dizi karakterleri ile kurdukları para-sosyal ilişkinin marka beğenilirliğine yansıdığı sonucuna erişilmiştir. Tüketicilerin izledikleri dizilerdeki sevdikleri karakterlerle kurdukları para-sosyal ilişkilerin dizilerde ürün yerleştirme olarak yer alan markalara yönelik beğenilerinin oluşabileceği görülmektedir. $\mathrm{Bu}$ çerçevede özellikle dizi karakterleriyle yüksek düzeyde bir para-sosyal ilişki kuran tüketicilerin, karakterin dizide kullandığı markaya yönelik daha güçlü bir beğeni hissedeceği ön görülebilir. Dolayısıyla tüketicilerin dizi karakterleriyle kurdukları para-sosyal ilişkiden faydalanmak amaçlı ürün yerleştirme uygulamasına başvuran ve bu doğrultuda bir marka beğenilirliği oluşturmak isteyen işletmelerin, amaçlarına ulaşmak noktasında başarılı olabilecekleri düşünülmektedir.

$\mathrm{Bu}$ bağlamda araştırma sonucunda elde edilen bulgular, öncesinde ürün yerleştirme bağlamında tüketicilerin bilişsel ve duygusal değerlendirme bileşenleri ile para-sosyal ilişkiyi irdeleyen Dens vd. (2012), Schramm ve Knoll (2015), Yang ve Roskos-Ewoldsen (2007), Janiszewski (1993), Russell (2002), Knooll vd. (2015), Russell ve Stern (2006), Schemer vd. (2008), Labrecque (2014), Johnson ve Patnoe-Woodley (2016), Van Reijmersdal vd. (2007) çalışmalarıyla örtüşen sonuçlar elde edilmiştir. 
Gerçekleştirilen bu araştırma birtakım kısıtları içermektedir. Bu bağlamda belirli bir tüketici kitlesi üzerinde gerçekleştirildiğinden elde edilen sonuçların tüm markalara ve dizilere genellenmesi mümkün olmamaktadır. Bunun yanı sıra araştırma, zaman ve maliyet kısıtından dolayı Isparta ilinde ulaşılan örneklem çerçevesinde gerçekleştirilmiştir. İleride değişkenler arası ilişkiyi irdeleyen araştırmalarda, belirli bir marka veya dizi uygulaması özelinde uygulamalar gerçekleştirilebileceği varsayılmaktadır. Buna ek olarak, farklı demografik yapıdaki tüketiciler üzerinde uygulanabilecek araştırmalar, para-sosyal ilişki ile marka beğenilirliği ilişkisine yönelik literatüre farklı bakış açıları kazandırabileceği düşünülmektedir.

\section{EXTENDED ABSTRACT}

Brands that want to achieve a valuable and differentiating position in the consumer mind and want to reach a sustainable loyalty are important to ensure a brand likeability for individuals. Brand likeability, which includes cognitive and emotional components and is seen as a multidimensional structure (Nguyen, Melewar, \& Chen, 2013a, p.26), is considered as a psychological factor that shapes consumers' reactions to the marketing and communication activities of the brand (Nguyen, Choudhury, \& Melewar, 2015, p.123). In this context, businesses shape their communication activities in order to provide consumer likeability for their brands. At this point, one of the communication techniques that brands use to create consumer likeability is seen as product placement. With product placement, businesses introduce their brands to consumers through series characters, especially by taking part in the series followed by consumers for a fee (Balasubramanian, Karrh, \& Patwardhan, 2006, p. 115). Therefore, brands are trying to create a brand likeability in consumers with product placement practices that they realize by taking advantage of the para-social relationship that consumers have developed with series characters. Based on this assumption, it is aimed to examine whether the para-social relationship that consumers establish with series characters will reflect on brand likeability in the context of product placement. The fact that the relationship between variables will be dealt with for the first time is assumed to fill the gap in the literature. In addition, the research is expected to provide a supportive finding for future studies on brand likeability. In addition, this study is important in terms of conveying the reflection of para-social relationship to brand likeability to advertising and brand practitioners. In this direction, it was aimed to reach participants over 18 years of age with face-to-face questionnaire technique. In this context, data 
were collected from 422 participants in Isparta city with purposeful sampling due to time and cost constraints. Since the study was carried out for a specific consumer group and city, it is not possible to generalize the results to all brands and consumers. Structural equation modeling was used to test the hypothesis determined in the context of the research. In line with the analysis carried out, it was determined that the model output was between an acceptable fit and a perfect fit. In other words, the model created within the framework of the research is seen to be statistically significant and the hypothesis is confirmed. Therefore, within the scope of the research, it was found that the para-social interaction has a strong positive effect on brand likeability. Based on this finding, it can be stated that the para-social interaction has a high level of effect in explaining brand likeability. In other words, in the context of the sample reached within the framework of the research, it was concluded that the para-social relationship individuals establish with the characters of the series is reflected in the brand liking. In this context, it is seen that the para-social relationships that consumers establish with their favorite characters in the series they watch may develop their likeability for the brands that appear as product placement in the series. In this framework, it can be predicted that consumers who have a high level of para-social relationship with the characters of the series will feel a stronger likeability for the brand used by the character in the series. Therefore, it is thought that businesses that use product placement to benefit from the para-social relationship that consumers establish with series characters and want to create a brand likeability in this direction can be successful in achieving their goals. In this context, prior to the findings of the research (Dens et al., 2012; Schramm and Knoll, 2015; Yang and Roskos-Ewoldsen, 2007; Janiszewski, 1993; Russell, 2002; Knooll et al., 2015; Russell and Stern, 2006; Schemer et al., 2008; Labrecque, 2014; Johnson and Patnoe-Woodley, 2016; Van Reijmersdal et al. 2007), the results were consistent with the studies examining the cognitive and emotional evaluation components of consumers and the para-social relationship in the context of product placement. In this direction, it is assumed that practices specific to a particular brand or series application can be implemented in studies aiming to examine the interaction between brand likeability and parasocial relationship in the future. In addition, it is thought that researches that can be applied on consumers with different demographic structures can bring different perspectives to the literature on the relationship between para-social relationship and brand likeability. In addition to all these, it is assumed that the examination of the relationships between brand likeability 
and brand attitude, brand loyalty, brand attachment, and purchase intention will contribute to the brand likeability literature.

\section{KAYNAKÇA}

Özden, A. T. (2019). Kadın tüketicilerin özgüven düzeylerinin marka beğenilirlik düzeyleri üzerindeki etkisinin demografik özelliklerine göre farklılıkları. International Review of Economics and Management, 7(1), 115-138.

Özen, Y., \& Gül, A. (2007). Sosyal ve eğitim bilimleri araştırmalarında evren-örneklem sorunu. Atatürk Üniversitesi Kazım Karabekir Eğitim Fakültesi Dergisi, 15, 394-422.

Akıncı, S., \& Çakır, V. (2017). Para-sosyal ilişki teorisi perspektifinden ürün yerleştirme etkililiği. INIF E-Dergi, 2(2), 210-228.

Alan, R., \& Perse, E. (1987). Audience activity and soap opera involvement a uses and effects investigation. Human Communication Research, 14(2), 246-268.

Arda, S. (2006, Haziran). Predictors of para-social interaction with the favorite and the least desirable characters portrayed in TV serials. A Thesis Submitted To The Graduate School of Social Sciences of Middle East Technical University.

Babin, L., \& Carder, S. (1996). Viewers' recognition of brands placed within a film. International Journal of Advertising, 15(2), 140-151.

Baek, Y. M., Bae, Y., \& Jang, H. (2013). Social and parasocial relationships on social network sites and their differential relationships with users' psychological well-being. Cyberpsychology, Behaviour, and Social Networking, 16(7), 1-6.

Balasubramanian, S., Karrh, J., \& Patwardhan, H. (2006). Audience response to product placements: an integrative framework and future research agenda. Journal of Advertising, 35(3), 115-141.

Ballantine, P., \& Martin, B. (2005). Forming parasocial relationships in online communities. Advances in Consumer Research, 32, 197-201.

Branch, S., Wilson, K., \& Agnew, C. (2013). Committed to oprah, homer, or house: using the investment model to understand parasocial relationships. Psychology of Popular Media Culture, 2(2), 96-109.

Brennan, I., \& Babin, L. (2004). Brand placement and recognition: the influence of presentation mode and brand familiarity. Journal of Promotion Management, 10(1/2), 185-202.

Chung, S., \& Cho, H. (2017). Fostering parasocial relationships with celebrities on social media: implications for celebrity endorsement. Psychology \& Marketing, 34(4), 481495. 
Cohen, J. (1997). Parasocial relations and romantic attraction: gender and dating status differences. Journal of Broadcasting \& Electronic Media, 41(4), 279-292.

D'Astous, A., \& Chartier, F. (2000). A study of factors affecting consumer evaluations and memory of product placements in movies. Journal of Current Issues \& Research in Advertising, 22(2), 31-40.

Dens, N., De Pelsmacker, P., Wouters, M., \& Purnawirawan, N. (2012). Do you like what you recognize? Journal of Advertising, 41(3), 35-54.

Derrick, J., Gabriel, S., \& Tippin, B. (2008). Parasocial relationships and self-discrepancies: Faux relationships have benefits for low self-esteem individuals. Personal Relationships, 15, 261-180.

Devrani, T. (2009). Marka sadakati öncülleri: çalışan kadınların kozmetik ürün tüketimi üzerine bir çalışma. Süleyman Demirel Üniversitesi İktisadi ve İdari Bilimler Fakültesi Dergisi, 14(3), 407-421.

Eyal, K., \& Cohen, J. (2006). When good friends say goodbye: a parasocial breakup study. Journal of Broadcasting \& Electronic Media, 50(3), 502-523.

Gökaliler, E., \& Saatçioğlu, E. (2019). Markalara yönelik sanal dedikodu ve marka beğenilirliği ilişkisi üzerine bir araştırma. Akdeniz Üniversitesi İletişim Fakültesi Dergisi, 31, 171-194.

Gegez, E. (2015). Pazarlama araştırmaları. İstanbul: Beta Yayıncılık.

Horton, D., \& Wohl, R. (1956). Mass communication and para-social interaction. Psychiatry, 19(3), 215-229.

Hwang, K., \& Zhang, Q. (2018). Influence of parasocial relationship between digital celebrities and their followers on followers' purchase and electronic word-of-mouth intentions, and persuasion knowledge. Computers in Human Behavior, 87, 155-173.

Janiszewski, C. (1993). Preattentive mere exposure effects. Journal of Consumer Research, 20(3), 376-392.

Johnson, J. Q., \& Patnoe-Woodley, P. (2016). Exploring the influence of parasocial relationships and experiences on radio listeners' consumer behaviors. Communication Research Reports, 33(1), 40-46.

Karrh, J. (1998). Brand placement: a review. Journal of Current Issues \& Research in Advertising, 20(2), 31-49.

Karrh, J., McKee, K., \& Pardun, C. (2003). Practitioners' evolving views on product placement effectiveness. Journal of Advertising Research, 43(2), 138-149.

Kim, H., Ko, E., \& Kim, J. (2015). SNS users' para-social relationships with celebrities: social media effects on purchase intentions. Journal of Global Scholars of Marketing Science, 25(3), 279-294. 
Kim, J., \& Kim, I. (2018). Moral imagination, parasocial brand love, and customer citizenship behavior: travelers' relationship with sponsoring airline brands in the United States. Sustainability, 10, 1-18.

Knoll, J., Schramm, H., Schallhorn, C., \& Wynistorf, S. (2015). Good guy vs. bad guy: the influence of parasocial interactions with media characters on brand placement effects. International Journal of Advertising, 34(5), 720-743.

Kwon, S. E., Kim, E., Sung, Y., \& Yoo, C. Y. (2014). Brand followers. International Journal of Advertising, 33(4), 657-680.

Labrecque, L. (2014). Fostering consumer-brand relationships in social media environments: the role of parasocial interaction. Journal of Interactive Marketing, 28, 134-148.

Lee, J., \& Watkins, B. (2016). YouTube vloggers' influence on consumer luxury brand perceptions and intentions. Journal of Business Research, 69, 5753-5760.

Lim, H., \& Kumar, A. (2019). Variations in consumers' use of brand online social networking: a uses gratifications approach. Journal of Retailing and Consumer Services , 51, 450-457.

Liu, M., Liu, Y., \& Zhang, L. (2019). Vlog and brand evaluations: the influence of parasocial interaction. Asia Pacific Journal of Marketing and Logistics, 31(2), 419-436.

Lueck, J. A. (2015). Friend-zone with benefits: the parasocial advertising of Kim Kardashian. Journal of Marketing Communications, 21(2), 91-109.

Malhotra, N., \& Birks, D. (2000). Marketing research an apllied approach . Londra: Prentice Hall.

Matthes, J., Schemer, C., \& Wirth, W. (2007). More than meets the eye investigating the hidden impact of brand placements in television magazines. International Journal of Advertising, 20(3), 376-392.

Narteh, B. (2018). Brand equity and financial performance. The moderating role of brand likeability. Marketing Intelligence \& Planning, 36(1), 381-395.

Nelson, M. (2002). Recall of brand placements in computer/video games. Journal of Advertising Research, 42(2).

Nguyen, B., Choudhury, M. M., \& Melewar, T. (2015). An integrated model of firms' brand likeability: antecedents and consequences. Journal of Strategic Marketing , 23(2), 122-140.

Nguyen, B., Ekinci, Y., Simkin, L., \& Melewar, T. (2015). The brand likeability scale. An exploratory study of likeability in firm-level brands. International Journal of Market Research, 57(5), 777-800.

Nguyen, B., Melewar, T., \& Chen, J. (2013a). The brand likeability effect: Can firms make themselves more likeable? Journal of General Management, 38(3), 25-50. 
Nguyen, B., Melewar, T., \& Chen, J. (2013b). A framework of brand likeability: an exploratory study of likeability in firm-level brands. Journal of Strategic Marketing, 21(4), 368-390.

Oyman, M., \& Akıncı, S. (2019). Sosyal medya etkileyicileri olarak vloggerlar: z kuşağı üzerinde para-sosyal ilişki, satın alma niyeti oluşturma ve Youtube davranışları açısından vloggerların incelenmesi. Akdeniz Üniversitesi İletişim Fakültesi Dergisi, $32,441-464$.

Perse, E., \& Rubin, R. (1989). Attribution in social and parasocial relationships. Communication Research, 16(1), 59-77.

Reysen, S. (2005). Construction of a new scale: The Reysen likability scale. Social Behavior and Personality, 33(2), 201-208.

Rubin, A., \& Perse, E. (1987). Audience activity and soap opera involvement a uses and effects investigation. Human Communication Research, 14(2), 246-268.

Rubin, A., Perse, E., \& Powell, R. (1985). Loneliness, parasocial interaction, and local television news viewing. Human Communication Research, 12(2), 155-180.

Rusell, C. A. (2002). Investigating the effectiveness of product placements in television shows: the role of modality and plot connection congruence on brand memory and attitude. . Journal of Consumer Research, 29(3), 306-318.

Rusell, C. A., \& Belch, M. (2005). A managerial investigation into the product placement industry. Journal of Advertising Research, 45(1), 73-92.

Rusell, C. A., \& Stern, B. (2006). Consumers, characters, and products: a balance model of sitcom product placement effects. Journal of Advertising, 35(1), 7-21.

Rusell, M., Fortunato, J., Valencia, L., \& Burns, N. (2003). Brand perceptions of TV commercials during Super Bowl XXXVIII. Working Paper. Texas: University of Texas.

Schemer, C., Matthes, J., Wirth, W., \& Textor, S. (2008). Does "passing the courvoisier" always pay off? Positive and negative evaluative conditioning effects of brand placements in music videos. Psychology \& Marketing, 25(10), 923-943.

Schramm, H., \& Knoll, J. (2015). Modeling the impact of parasocial interactions with media characters on brand placement effects. Journal of Promotion Management, 21, 548565 .

Scott, J., \& Craig-Lees, M. (2010). Audience engagement and its effects on product placement recognition. Journal of Promotion Management, 16(1-2), 39-58.

Smit, E., Van Reijmersdal, E., \& Neijens, P. (2009). Today's practice of brand placement and the industry behind it. International Journal of Advertising, 28(5), 761-782.

Soyadı, A. (2020, Temmuz). Çalışma Başlığı. Selçuk İletişim, 13(2), 1-12. 
Sung, Y., Kim, Y., Kwon, O., \& Moon, J. (2010). An explorative study of Korean consumer participation in virtual brand communities in social network sites. Journal of Global Marketing, 23(5), 430-445.

Taşdelen, B. (2020). Dijital çağın yeni trendi sosyal medya etkileyicileri: vloggerların üniversite öğrencilerinin satın alma davranışı üzerindeki etkisi. Gaziantep University Journal of Social Sciences, 19(3), 1071-1098.

Tsiotsou, R. (2015). The role of social and parasocial relationships on social networking sites loyalty. Computers in Human Behavior, 48, 401-414.

Van Reijmersdal, E. (2009). Brand placement prominence: good for memory! Bad for attitudes? Journal of Advertising Research, 49(2), 151-153.

Van Reijmersdal, E., Neijens, P., \& Smit, E. (2007). Effects of television brand placement on brand image. Psychology \& Marketing, 24(5), 403-420.

Van Reijmersdal, E., Neijens, P., \& Smit, E. (2009). A new branch of advertising reviewing factors that influence reactions to product placement. Journal of Advertising Research, 49(4), 429-449.

Williams, K., Petrosky, A., Hernandez, E., \& Page, R. (2011). Product placement effectiveness. Revisited and renewed. Journal of Management and Marketing Research, 7, 1-24.

Xiang, L., Zheng, X., Lee, M., \& Zhao, D. (2016). Exploring consumers' impulse buying behavior on social commerce platform: the role of parasocial interaction. International of Information Management, 36, 333-347.

Yüksekbilgili, Z. (2017). Marka beğenilirlik ölçeğinin Türkçeye uyarlanması güvenilirlik ve geçerlilik çalışması. Journal of Yasar University, 12(46), 171-180.

Yang, M., \& Roskos-Ewoldsen, D. (2007). The effectiveness of brand placements in the movies: levels of placements, explicit and implicit memory, and brand-choice behavior. Journal of Communication, 57, 469-489.

Ye, G., \& Van Raaij, F. (2004). Brand equity: extending brand awareness and liking with Signal Detection Theory. Journal of Marketing Communication, 10(2), 95-114. 